\title{
PERANCANGAN SISTEM INFORMASI KELENGKAPAN PENGISIAN FORMULIR INFORMED CONSENT DI RS AL ISLAM BANDUNG
}

\author{
Yudhi Yanuar \\ Yudhi.yanuar@piksi-ganesha-online.ac.id \\ Putri Damayanti \\ putri.putraningsih@gmail.com
}

\begin{abstract}
This study aimed to determine medical action approval form completeness (informed consent) information system design using Microsoft Visual Studio 2010 usage in Rumah Sakit Al Islam Bandung. The research used qualitative method with descriptive approach. While data collection techniques used by direct observations, interviews and completed with a literate review that had a relationship to the subject matter. The development method used was Waterfall. From making this information system the writer used programming language Microsoft Visual Studio 2010 and storage of data using Microsoft Access 2007. From the results conducted there were some problems found, such as:lack in socialization of standard operating procedure for informed consent making, many informed consent forms are still not filled in completely, this is unfortunate given the importance of legal aspects contained in informed concent and, proses of analyzing for completeness informed consent form are still uses Microsoft Excel, so that analysis time becomes longer. The suggestions were given by: (1). Socializing the standard operating procedure of making an informed consent to the relevant officers;(2).Developinga new information system for the data processing analysis the completeness of informed consentfilling for producing reports more accurate and time efficiency in the analysis process.
\end{abstract}

Keyword : Completeness, Informed Consent, Microsoft Visual Studio 2010

\section{PENDAHULUAN}

Kesehatan adalah keadaan dari badan, jiwa, sejahtera dan sosial yang memungkinkan setiap orang untuk hidup produktif secara sosial dan ekonomi.

Hal ini sesuai dengan salah satu tujuan nasional yang tertuang dalam pembukaan UndangUndang dasar 1945 yaitu memajukan kesejahteraan umum dan pasal $28 \mathrm{H}$ ayat (1) yaitu setiap orang berhak hidup sejahtera lahir dan batin, bertempat tinggal, dan mendapatkan lingkungan hidup yang baik dan sehat serta berhak memperoleh pelayanan kesehatan. Menurut Permenkes No.1045/Menkes/Per/XI/2006 tentang pedoman Organisasi Rumah Sakit di lingkungan Depkes, yang menyebutkan Rumah Sakit adalah suatu fasilitas pelayanan kesehatan jangka pendek dan jangka panjang yang terdiri atas observasi, diagnostik, terapeutik, dan rehabilitative untuk orangorang yang menderita sakit, cedera, dan melahirkan. Sarana upaya kesehatan yang menyediakan kegiatan pelayanan kesehatan serta dapat dimanfaatkan untuk tenaga kesehatan dan penelitian.

Unit rekam medis sebagai salah satu unit yang ada di rumah sakit yang bertugas untuk mengumpulkan, mengelola dan menganalisa semua berkas yang berisikan catatan dan dokumen tentang identitas pasien, pemeriksaan, pengobatan, tindakan dan pelayanan lain yang telah diberikan kepada pasien. Rekam medis adalah unit yang memberikan pelayanan pertama pada saat pasien berkunjung ke rumah sakit oleh sebab itu unit rekam medis harus senantiasa berusaha memberikan pelayanan yang terbaik kepada pasien serta memberikan suatu informasi yang tepat, cepat dan akurat demi tercapainya tertib administrasi.

Salah satu lembar medis yang harus diperhatikan kelengkapannya adalah formulir persetejuan tindakan medis/kedokteran atau informed consent. Menurut PerMenkes No.290/MenKes/Per/III/2008, UU No 29 tahun 2004 Pasal 45, dan Manual Persetejuan Tindakan Kedokteran KKI tahun 2008 
Informed Consent adalah persetujuan tindakan kedokteran yang diberikan oleh pasien atau keluarga terdekatnya setelah mendapatkan penjelasan secara lengkap mengenai tindakan kedokteran yang akan dilakukan terhadap pasien tersebut.

Kelengkapan isi Informed Consent harus memuat data yang lengkap sehingga pasien, dokter dan rumah sakit dapat mencegah terjadinya kasus-kasus hukum. Hal yang harus diperhatikan dalam pengisian Informed Consent adalah kelengkapan nama dan tanda tangan oleh dokter dan keluarga pasien.

Kondisi di Rumah Sakit Al Islam pada pengisian lembar persetujuan tindakan kedokteran yang masih terdapat ketidaklengkapan dalam pengisian tanda tangan dokter, saksi . Dan sistem yang ada masih menggunakan Microsoft Excel sehingga dalam pelaksanaannya masih belum optimal.

\section{A. POKOK PERMASALAHAN}

Berdasarkan latar belakang penelitian dan fakta diatas maka pokok permasalahnnya adalah bagaimana Perancangan Sistem Informasi Kelengkapan Pengisian Formulir Informed Consent Menggunakan Microsoft Visual Studio 2010 di Rumah Sakit Al Islam Bandung guna mempermudah pelaporan kelengkapan pengisian formulir Informed Consent di wilayah kerja Rumah Sakit Al Islam Bandung.

\section{B. RENCANA PEMECAHAN MASALAH}

Berdasarkan hasil penelitian pada permasalahan yang terjadi maka penulis akan membuat sistem informasi kelengkapan pengisian formulir Informed Consent menggunakan Microsoft Visual Studio 2010 di Rumah Sakit Al Islam Bandung.

\section{TUJUAN DAN MANFAAT PENELITIAN}

\section{TUJUAN PENELITIAN}

Penelitian ini bertujuan untuk mengetahui sistem pengolahan data kelengkapan pengisian formulir Informed Consent serta untuk mengetahui perancangan sistem informasi kelengkapan pengisian formulir Informed Consent di Rumah Sakit Al Islam Bandung.

\section{MANFAAT PENELITIAN}

a. Manfaat bagi penulis : Sebagai bahan perbandingan teori dan materi perkuliahan yang didapat, khususnya pada jurusan Informatika Rekam Medis (IRM). Dengan harapan dapat menambah wawasan dan pengetahuan baik secara teoritis maupun praktek lapangan dan penelitian mengenai Perancangan Sistem Informasi Pengisian Formulir Informed Consent Menggunakan Microsoft Visual Studio 2010 di Rumah Sakit Al Islam Bandung.

b. Akademik : Sebagai ilmu, referensi, maupun wawasan bagi institusi, seluruh mahasiswa tentang Perancangan Sistem Informasi Pengisian Formulir Informed Consent Menggunakan Microsoft Visual Studio 2010 di Rumah Sakit Al Islam Bandung dan menjadi tambahan sumbangsih bagi ilmu pengetahuan pada sistem informasi.

c. Manfaat bagi Puskesmas : Sebagai bahan pertimbangan bagi puskesmas dalam pengembangan Sistem Informasi Pengisian Formulir Informed Consent Menggunakan Microsoft Visual Studio 2010 di Rumah Sakit Al Islam Bandung.

\section{KAJIAN TEORITIS}

\section{A. Pengertian Rumah Sakit}


Rumah sakit adalah "sarana upaya kesehatan yang menyelenggarakan kegiatan pelayanan kesehatan serta dapat dimanfaatkan untuk pendidikan tenaga kesehatan dan penelitian” (PERMENKES RI No. 159b/Per/II/1998).).

\section{B. Pengertian Rekam Medis}

Rekam medis adalah berkas yang berisikan catatan dan dokumen tentang identitas pasien, pemeriksaan, pegobatan, tindakan dan pelayanan lain yang telah diberikan kepada pasien (PERMENKES No 269 Tahun 2008).

\section{Pengertian RKE}

Penyebutan EMR (Electronic Medical Record) sering dipertukarkan dengan Computer Based Patient Recod (CPR) untuk menyatakan suatu sistem berbasis komputer yang dimanfaatkan untuk mengelola informasi pelayanan pasien (Gemala Hatta, 2013 : 292).

D. Pengertian Analisis

Analisis adalah segenap rangkaian perbuatan pikiran yang mencegah sesuatu hal secara mendalam mengetahui cirri, hubungan dan peranan dalam kebutuhan yang dibuat (direktorat jendral pelayanan medis 2006;76).

Analisis kuantitatif adalah telah/ review bagian tertentu dari isi rekam medis dengan maksud menemukan kekurangan khusus yang berkaitan dengan pencatatan rekam medis. Dapat disebut juga sebagai analisis ketidalengkapan baik dari segi formulir yang harus ada maupun dari segi kelengkapan pengisian semua item pertanyaan yang ada pada formulir sesuai dengan pelayanan yang diberikan pada pasien (Huffiman, $1999 ; 22$ ).

Analisis kualitatif adalah suatu review pengisisn rekam medis yang berkaitan tentang kekonsistenan dan isinya merupakan bukti rekam medis tersebut akurat dan lengkap, konsistensi merupakan suatu penyesuaian atau kecocokan antara 1 bagian dengan bagian lain dan dengan seluruh bagian ,dimana diagnosa dari awal sampai akhir harus konsisten (Huffiman,1999; 25).

Analisis statistik yaitu mengolah data rekam medis yang tidak lengkap dan menyajikan angka ketidaklengkapan, sehingga dapat dijadikan pringatan untuk memperbaiki pencatatan rekam medis yang lengkap (Huffiman, 1999; 27).

\section{E. Pengertian Informed Consent}

Informed consent adalah persetujuan tindakan kedokteran yang diberikan oleh pasien atau keluarga terdekatnya setelah mendapatkan penjelasan secara lengkap mengenai tindakan kedokteran yang akan dilakukan terhadap pasien tersebut (Permenkes290/MenKes/Per/III/2008, UU No 29 tahun 2004 Pasal 45)

\section{F. Tujuan Informed Consent}

1. Melindungi pasien terhadap segala tindakan medis yang dilakukan tanpa sepengetahuan pasien, maupun tindakan jasa tindakan medis sewenang-wenang,tindakan malpraktek yang bertentangan dengan hak asasi pasien dan standar profesi medis.

2. Memberikan perlindungan hukum terhadap pelaksana tindakan medis dari tuntutan -tuntutan pihak pasien yang tidak wajar, serta akibat tindakan medis yang tak terduga dan bersifat negative

\section{G. Bentuk Informed Consent}

Menurut departemen kesehatan (2002), informed consent dibagi menjadi 2 bentuk ;

1. Implied consent, yaitu persetujuan yang dinyatakan secara tidak langsung. Contoh, saat dokter akan mengukur tekanan darah pasien, ia hanya mendekati pasien sambil membawa sfigmomanometer tanpa mengatakan apapun dan pasien langsung mengulung lengan bajunya ( meskipun tidak mengatakan apapun, sikap pasien menunjukan bahwa ia tidak keberatan terhadap tindakan yang akan dilakukan dokter) 
2. Express Consent, yaitu persetujuan yang dinyatakan dalam bentuk tulisan atau secara verbal. Sekalipun bentuk persetujuan secara tersirat dapat dibenarkan, namun sangat bijaksana bila persetujuan pasien dinyatakan dalam bentuk tertulis karena hal ini dapat menjadi bukti yang lebih kuat dalam masa mendatang.

\section{H. Pengertian Perancangan}

Perancangan sistem merupakan tahap selanjutnya setelah analisa sistem, mendapatkan gambaran dengan jelas tentang apa yang dikerjakan pada analisa sistem, maka dilanjutkan dengan memikirkan bagaimana membentuk sistem tersebut. Perancangan sistem adalah suatu fase dimana diperlukan suatu keahlian perancangan untuk elemen-elemen komputer yang akan menggunakan sistem yaitu pemulihan peralatan dan program komputer untuk sistem yang baru (Andi Krisnanto, $2008: 61$ ).

\section{Pengertian Sistem}

Sistem adalah suatu jaringan kerja dari prosedur-prosedur yang saling berhubungan, berkumpul bersama-sama melakukan kegiatan atau untuk melakukan sasaran yang tertentu. Pendekatan sistem yang merupakan jaringan kerja dari prosedur lebih menekankan urutanurutan operasi didalam sistem (Jeperson H, $2015: 2$ ).

\section{J. Pengertian Informasi}

Informasi adalah data yang diolah menjadi bentuk yang lebih berguna dan lebih berarti bagi penerimanya. Sumber informasi adalah data. Data kenyataan yang menggambarkan suatu kejadian-kejadian dan kesatuan nyata. Kejadian-kejadian (event) adalah kejadian yang terjadi pada saat tertentu (Jeperson H, 2015 : 9).

\section{K. Pengertian Sistem Informasi}

Sistem informasi adalah suatu sistem dalam organisasi yang mempertemukan kebutuhan pengelolaan transaksi harian, mendukung operasi, bersifat manajerial, dan kegiatan strategi dari suatu organisasi dan menyediakan pihak luar tertentu dengan laporan-laporan yang dibutuhkan (Jeperson H, $2015: 13$ ).

\section{Pengertian Visual Basic.Net}

VB.NET adalah salah satu bahasa pemrograman Komputer Tingkat Tinggi. Bahasa Pemrograman adalah perintah-perintah yang dimengerti oleh komputer untuk melakukan tugas-tugas tertentu. Bahasa pemrograman VB.NET dikembangkan oleh Microsoft, Merupakan salah satu bahasa pemrograman yang Object Oriented Program (OOP) atau Pemrograman yang berorientasi pada Object. kata "Visual" menunjukkan cara yang digunakan untuk membuat Graphical User Interface (GUI).

Dengan Cara ini, kita tidak perlu lagi menuliskan instruksi pemrograman dalam kodekode baris hanya untuk membuat sebuah Desaign Form/Aplikasi. Tetapi dengan sangat mudah yakni kita cukup melakukan Drag and drop object-object yang akan kita gunakan. VB.Net dapat kita jadikan alat bantu untuk membuat berbagai macam program computer. Aplikasi VB.NET hanya dapat dijalankan pada system Operasi Windows (Hary Gunarto, $2006: 10$ ).

\section{Pengertian Microsoft Acces 2007}

Microsoft Access 2007 yang untuk selanjutnya disingkat Access 2007 adalah suatu program aplikasi basis data komputer relasional yang digunakan untuk merancang, membuat dan mengolah berbagai jenis data dengan kapasitas yang besar (Hary Gunarto, 2006 : 75).

\section{N. Pengertian Flowmap}

Pengertian flowmap adalah "Diagram yang menunjukan arus pekerjaan secara keseluruhan dari sistem. Diagram ini mnejelaskan urutan dari prosedur-prosedur yang ada di dalam sistem. Flowmap menunjukan apa yang dikerjakan di sistem" (Jogiyanto 2005:296).

\section{O. Pengertian Data Flow Diagram (DFD)}


Data Flow Diagram (DFD) adalah perangkat-perangkat analisis dan perancangan yang terstruktur sehingga memungkinkan peng-analisa sistem memahami sistem dan sub sistem secara visual sebagai suatu rangkaian aliran data yang saling berkaitan (Ladjamuddin 2005:72).

P. Pengertian Entity Relationship Diagram (ERD)

ERD merupakan suatu model untuk menjelaskan hubungan antar data dalam basis data berdasarkan objek-objek dasar data yang mempunyai hubungan antar relasi (Yakub 2008, 26).

\section{Q. Pengertian Kamus Data}

Kamus Data adalah katalog fakta tentang data dan kebutuhan-kebutuhan informasi dari sistem informasi (Husni Iskandar Pohan, dkk, 2012: 37).

\section{METODE PENELITIAN}

Metode penelitian yang digunakan adalah metodologi penelitian deskriptif. Metode deskriptif adalah metode yang digunakan untuk menggambarkan atau menganalisis suatu hasil penelitian. Pada penelitian ini penulis menggambarkan keadaan yang terjadi dilapangan khususnya mengenai analisis kelengkapan pengisian formulir Informed Consent dan membandingkan dengan teori yang ada kemudian membuat perancangan sistem informasi kelengkapan pengisian formulir Informed Consent di Rumah Sakit Al Islam Bandung.

Metode Pengembangan yang digunakan penulis adalah model air terjun (waterfall) biasa juga disebut siklus hidup perangkat lunak. Mengambil kegiatan dasar seperti spesifikasi, pengembangan, validasi, dan evolusi dan merepresentasikannya sebagai fase-fase proses yang berbeda seperti spesifikasi persyaratan, perancangan perangkat lunak, implementasi, pengujian dan seterusnya.

\section{HASIL DAN PEMBAHASAN}

Alur kelenlirgkapan pengisian formulir Informed Consent yang sedang dirancang ini menggunakan bahasa pemograman Object Oriented Program (OOP) atau Pemrograman yang berorientasi pada Object. Dimana sistem yang dirancang merupakan aliran data yang berorientasi pada objek-objek yang ada.

\section{A. Flowmap}




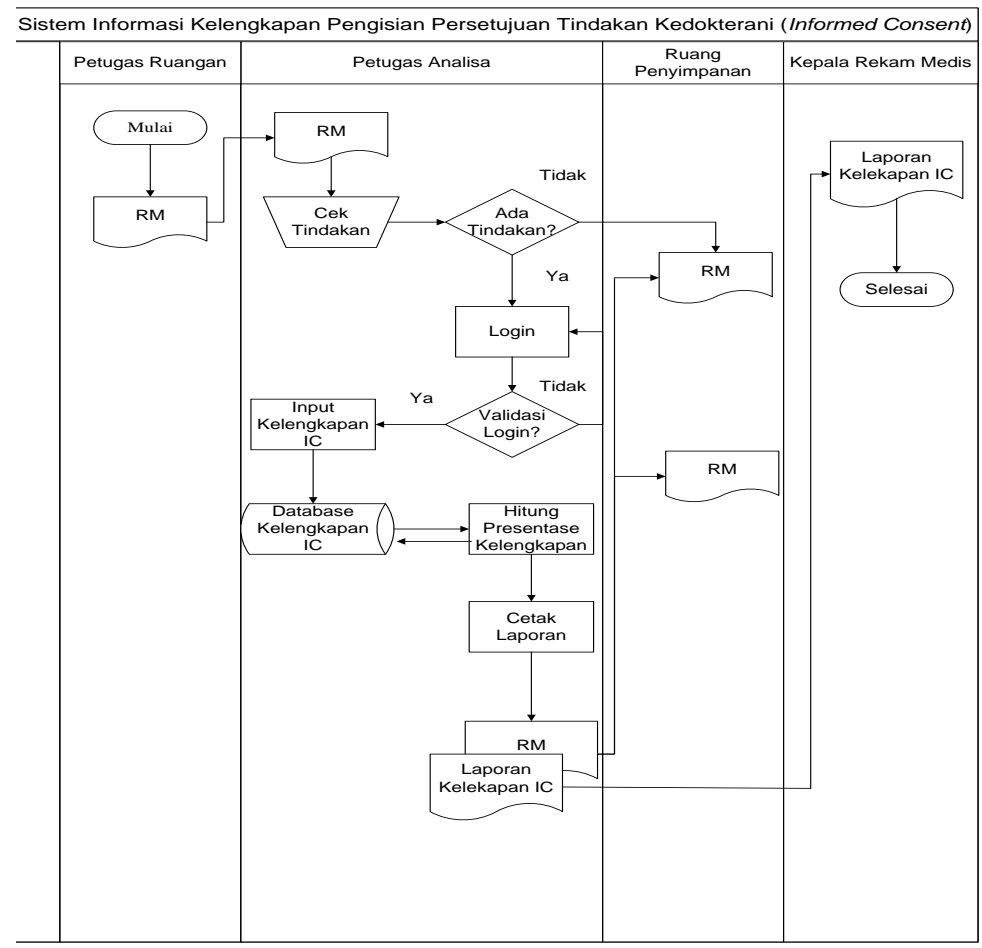

Gambar 1. Flowmap yang Sedang Dirancang

Sumber : Penulis 2017

\section{B. Diagram Context}

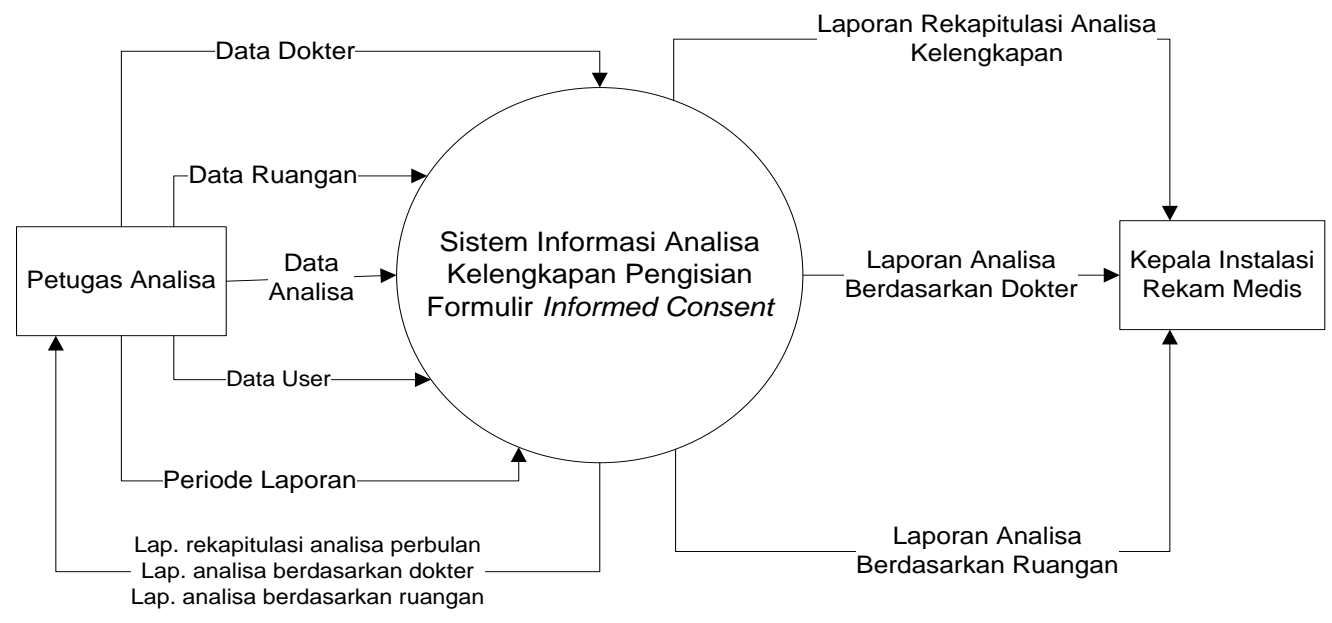

Gambar 2. Diagram Context yang Sedang Dirancang

Sumber : Penulis 2017

\section{Data Flow Diagram Level 0}




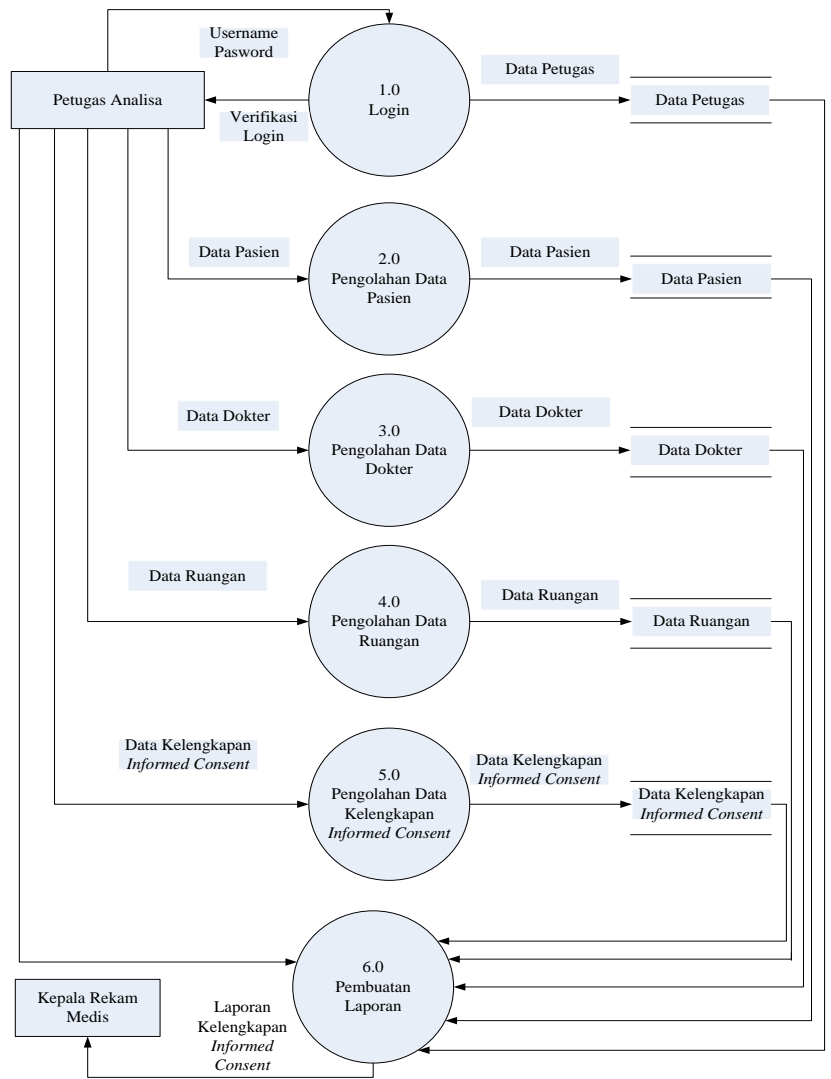

Gambar 3. Data Flow Diagram Level 0 yang Sedang Dirancang Sumber : Penulis 2017

D. Data Flow Diagram Level 1 Proses 1.0

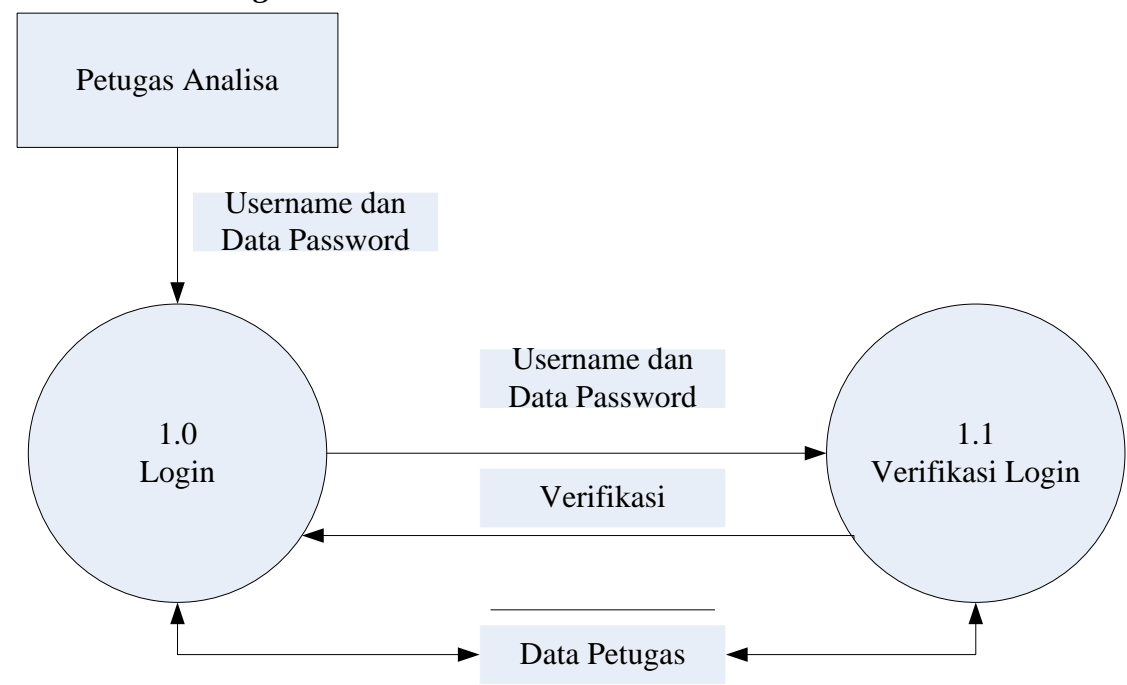

Gambar 4. Data Flow Diagram Level 1 Proses 1.0 yang Sedang Dirancang Sumber : Penulis 2017

E. Data Flow Diagram Level 1 Proses 2.0 


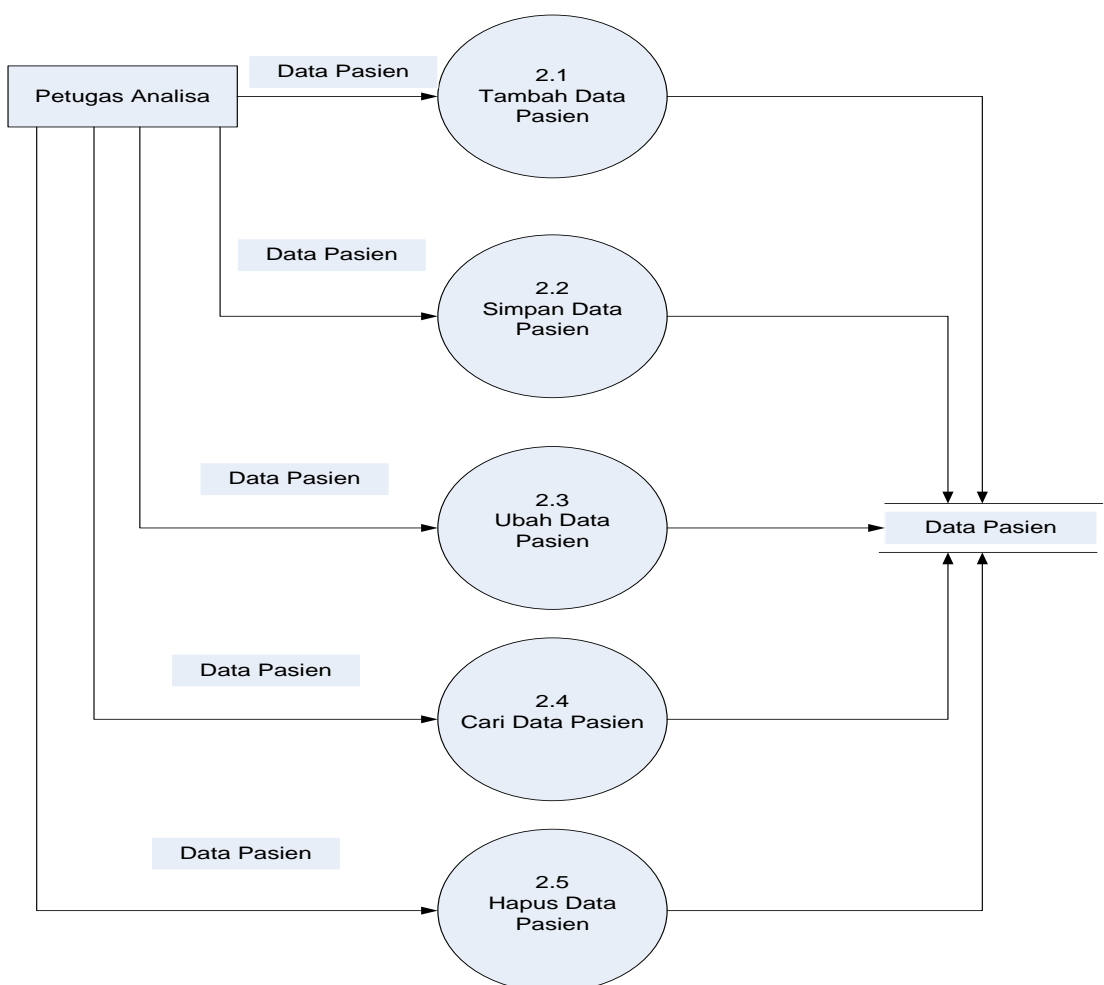

Gambar 5. Data Flow Diagram Level 1 Proses 2.0 yang Sedang Dirancang Sumber : Penulis 2017

F. Data Flow Diagram Level 1 Proses 3.0

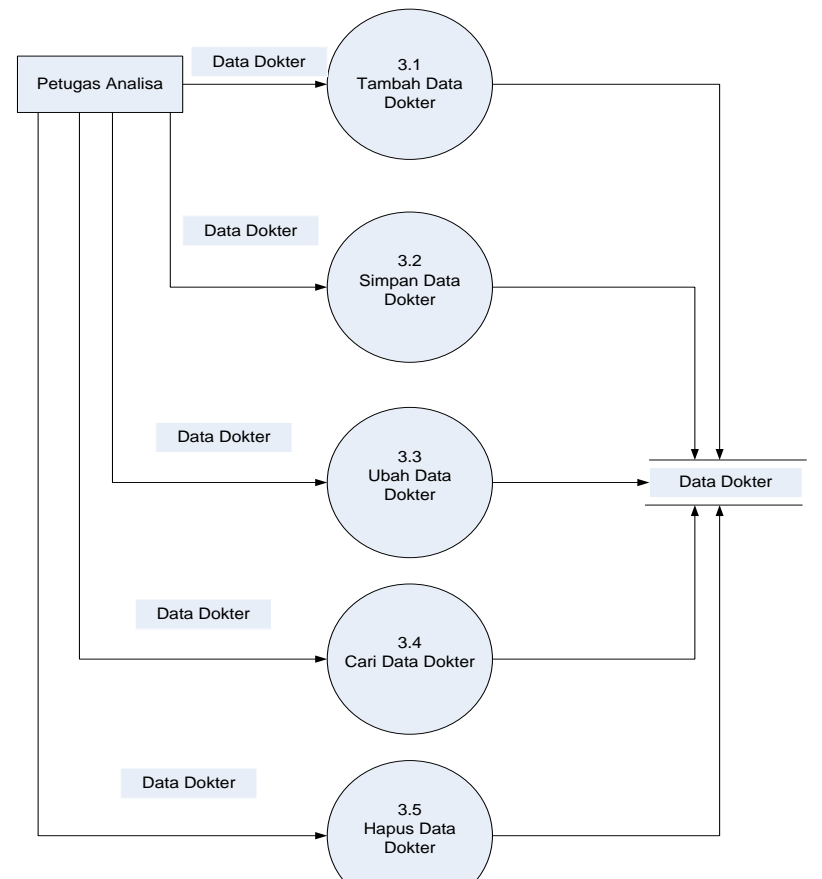

Gambar 6. Data Flow Diagram Level 1 Proses 3.0 yang Sedang Dirancang Sumber : Penulis 2017

G. Data Flow Diagram Level 1 Proses 4.0 


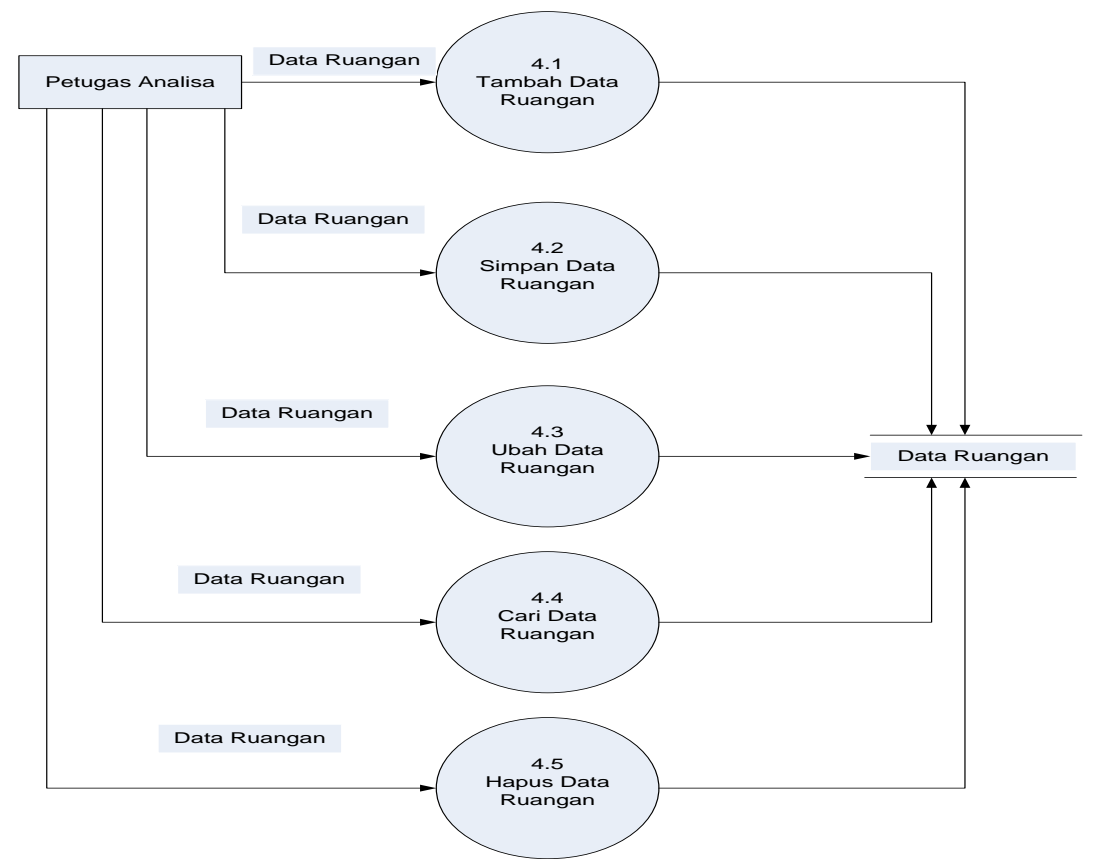

Gambar 7. Data Flow Diagram Level 1 Proses 4.0 yang Sedang Dirancang Sumber : Penulis 2017

H. Data Flow Diagram Level 1 Proses 5.0

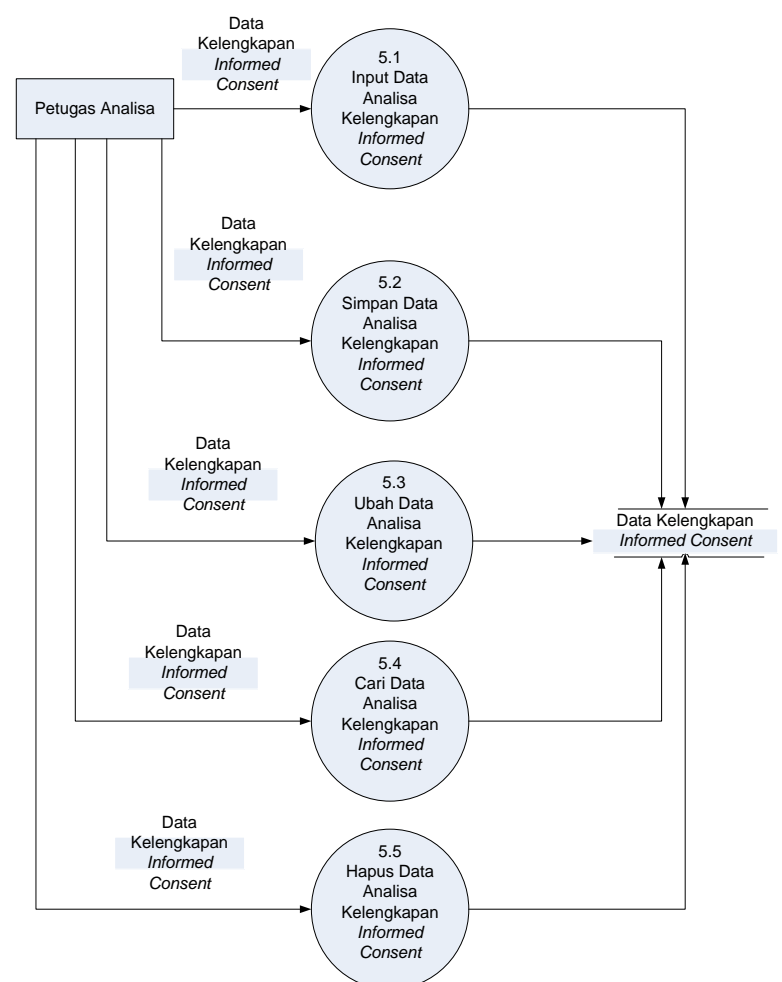

Gambar 8. Data Flow Diagram Level 1 Proses 5.0 yang Sedang Dirancang Sumber : Penulis 2017

I. Data Flow Diagram Level 1 Proses 6.0 


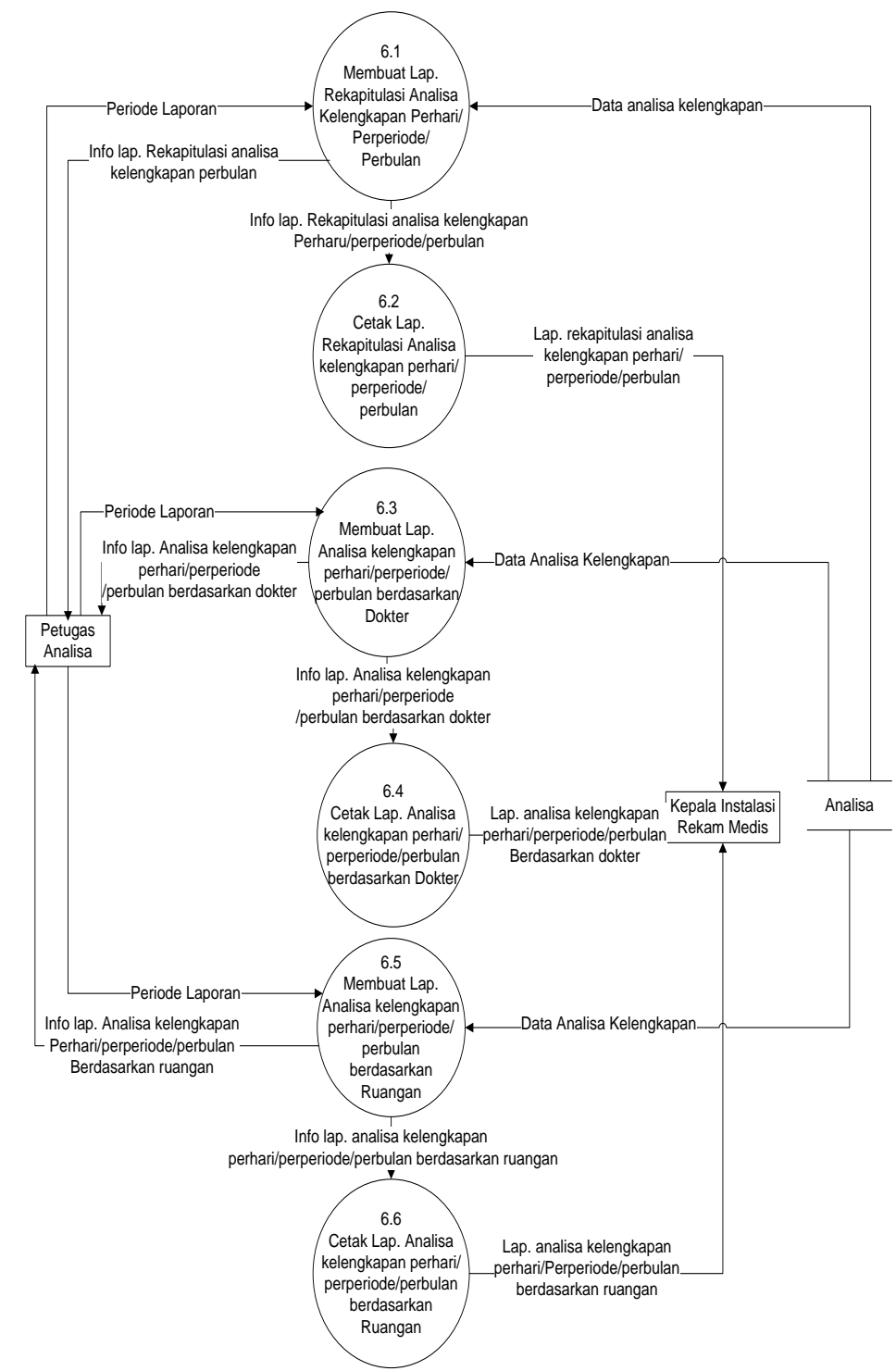

Gambar 9. Data Flow Diagram Level 1 Proses 6.0 yang Sedang Dirancang Sumber : Penulis 2017 
J. Entity Relationship Diagram (ERD)

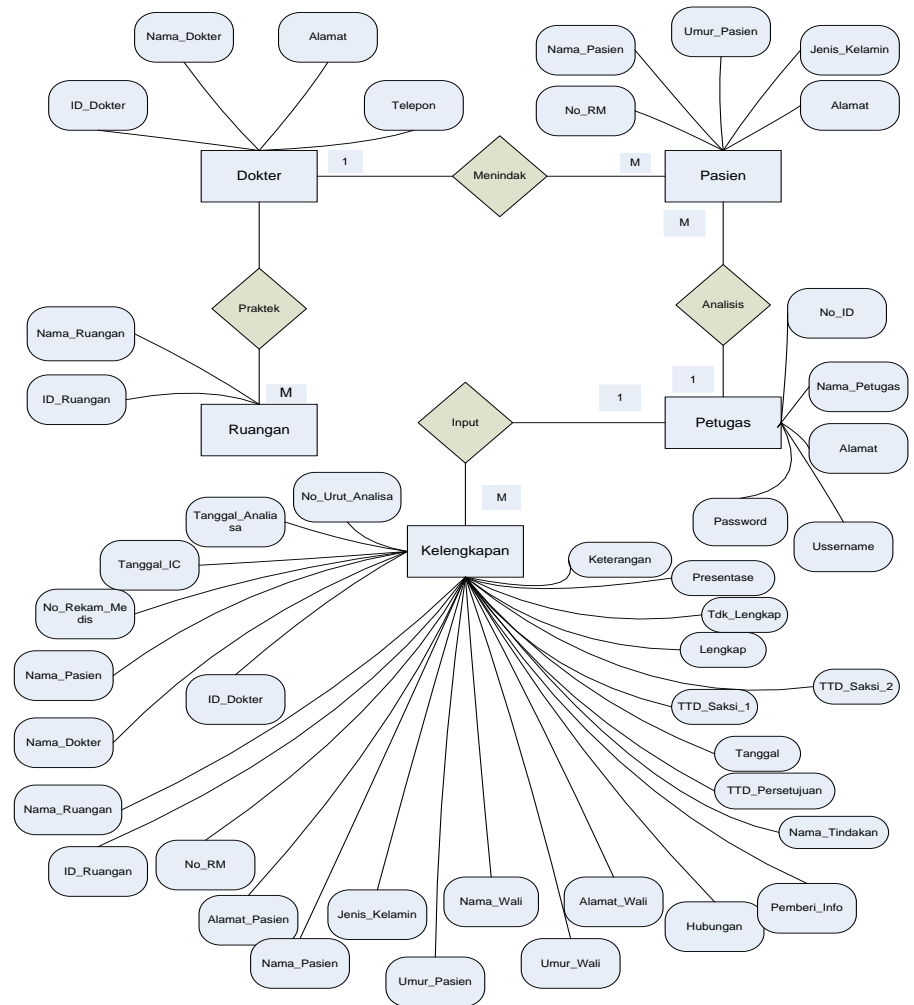

Gambar 10. Entity Relationship Diagram (ERD) yang Sedang Dirancang Sumber : Penulis 2017

\section{K. Relasi Antar Tebel}

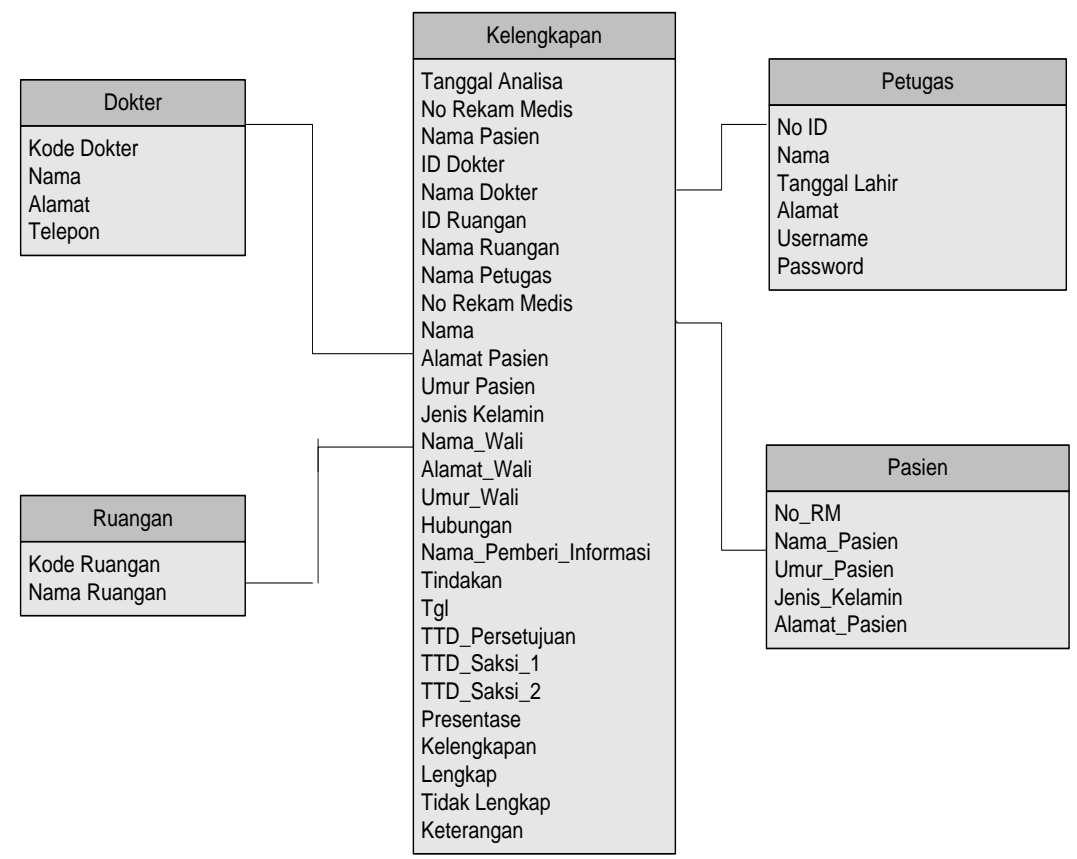

Gambar 11. Relasi Antar Tabel yang sedang dirancang Sumber : Penulis 2017

\section{Spesifikasi Proses}


Pada Sistem Informasi Kelengkapan Pengisian Formulir Informed Consent memiliki spesifikasi proses yang berfungsi sebagai alur proses berjalannya sistem informasi. Yaitu proses login, olah data pasien, olah data dokter, olah data ruangan, olah data analisa kelengkapan pengisian informed consent, dan membuat laporan.

\section{Rancangan Masukan}

Rancangan Masukan merupakan penjelasan rinci mengenai pemasukan data yang dibutuhkan oleh sistem,kemudian akan diproses oleh sistem sehingga menghasilkan suatu keluaran/hasil yang dibutuhkan oleh pengguna.

\section{N. Rancangan Keluaran}

Rancangan keluaran merupakan penjelasan informasi yang didapat setelah masukan data berhasil di proses.

\section{O. Implementasi Sistem}

1. Tampilan Splash Screen

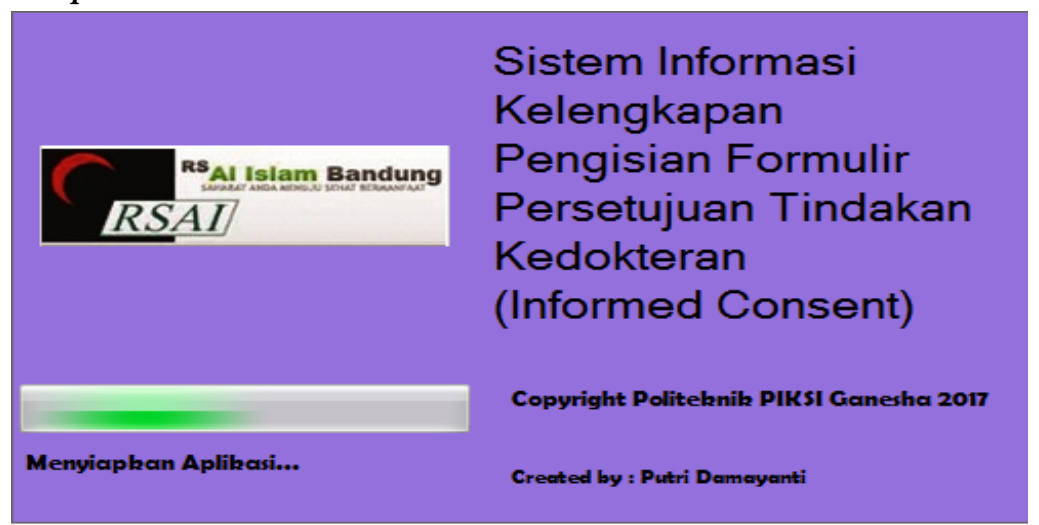

Gambar 12. Tampilan Splash Screen

Sumber : Penulis 2017

2. Halaman Login

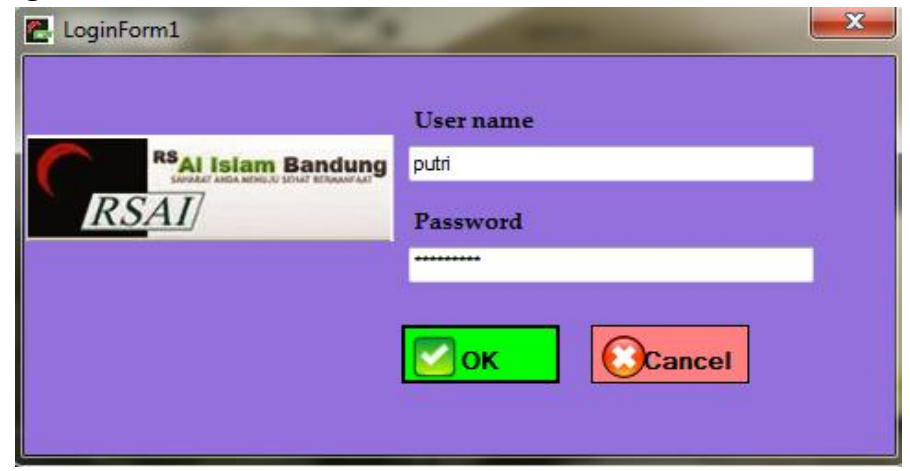

Gambar 13. Halaman Login

Sumber: Penulis 2017

\section{Halaman Utama}




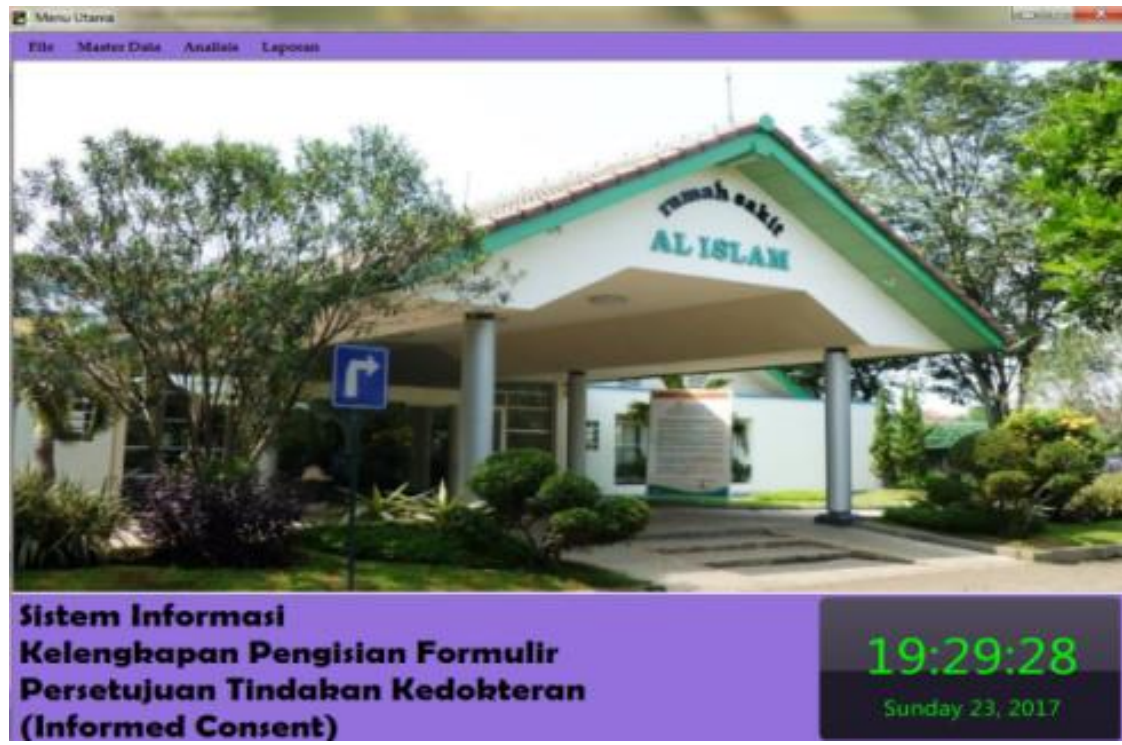

Gambar 14. Halaman Utama

Sumber : Penulis 2017

\section{Olah Data Dokter}

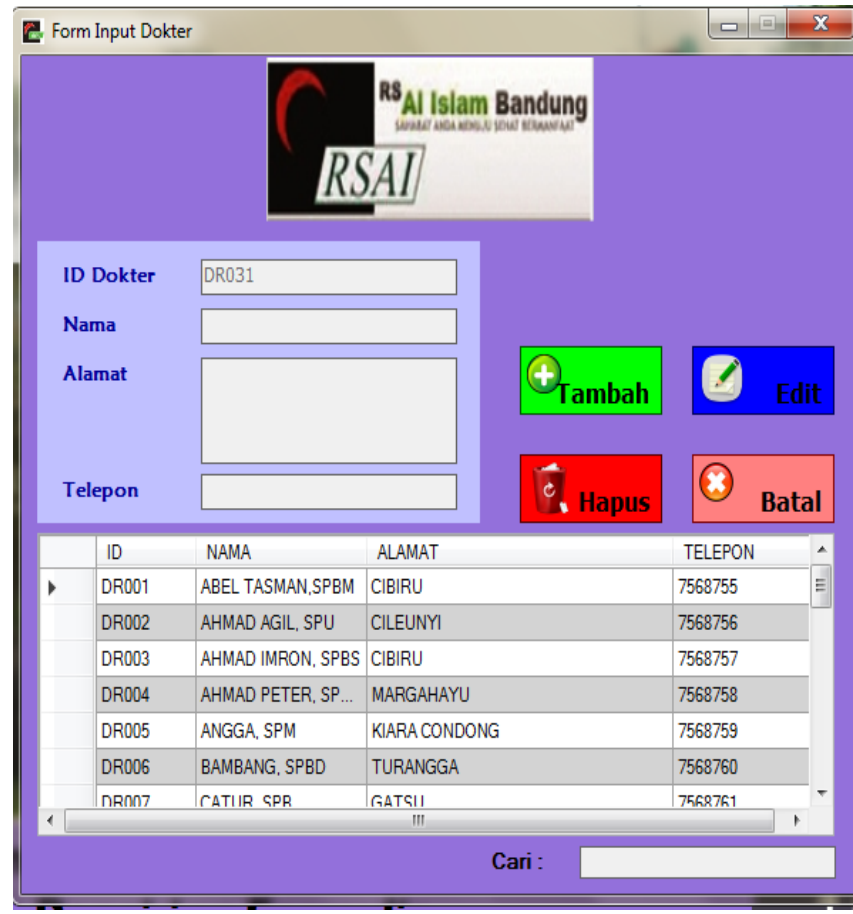

Gambar 15. Olah Data Dokter

Sumber : Penulis 2017

\section{Olah Data Pasien}




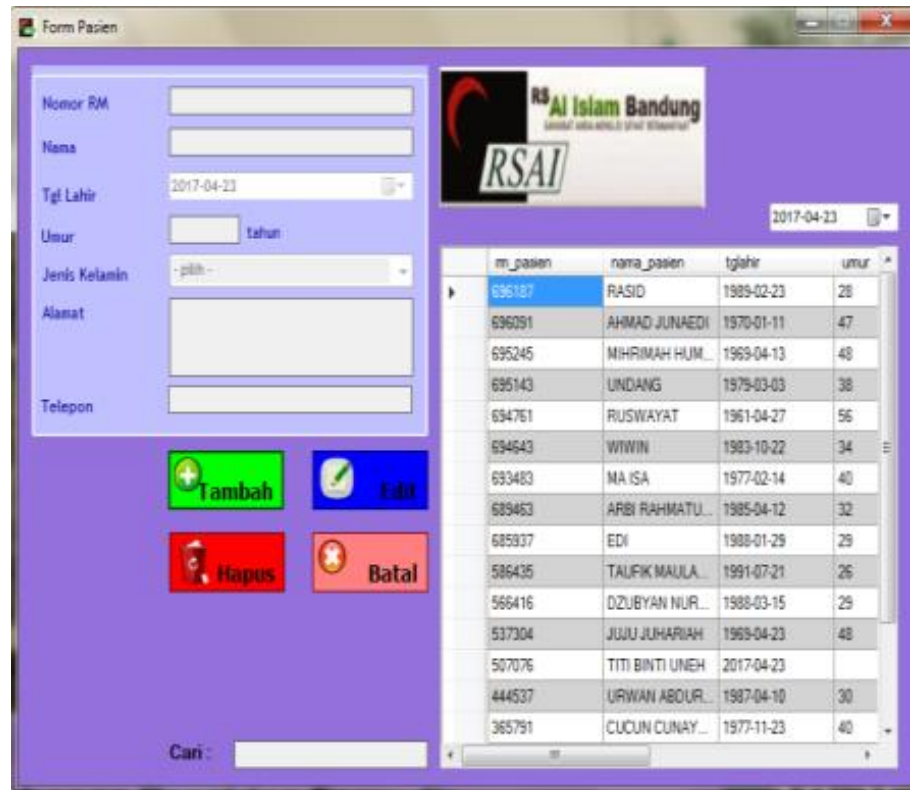

Gambar 16. Olah Data Pasien

Sumber : Penulis 2017

\section{Olah Data Petugas}

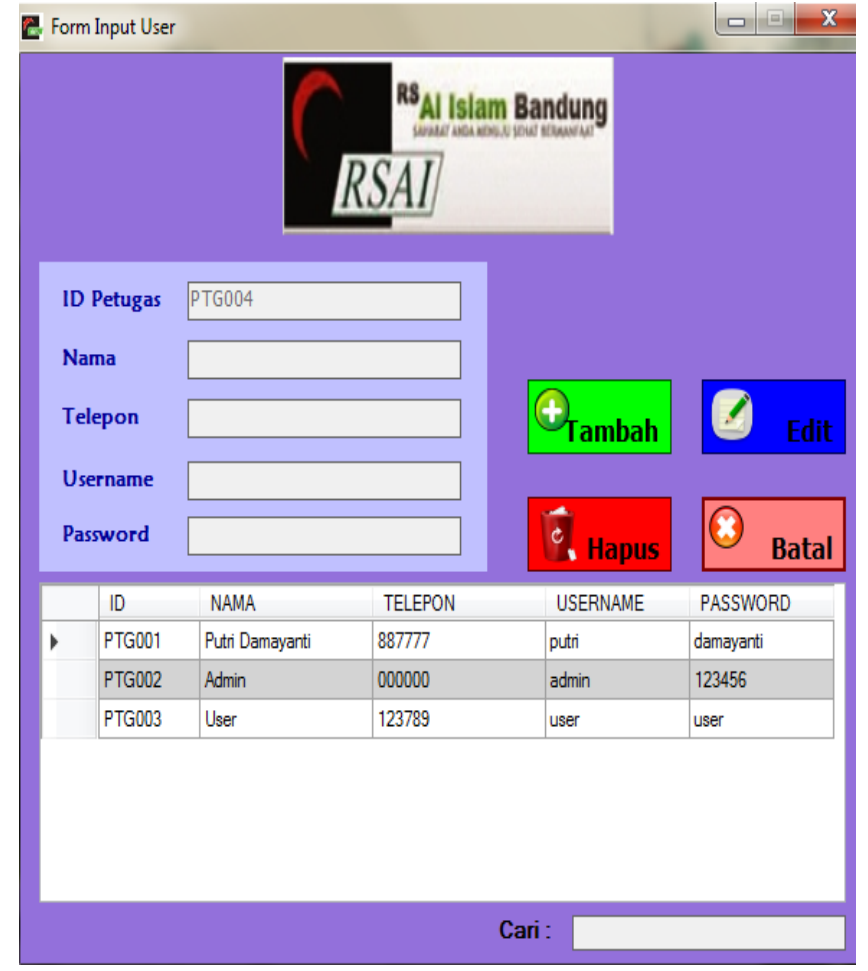

Gambar 17. Olah Data Petugas

Sumber : Penulis 2017

7. Olah Data Ruangan 


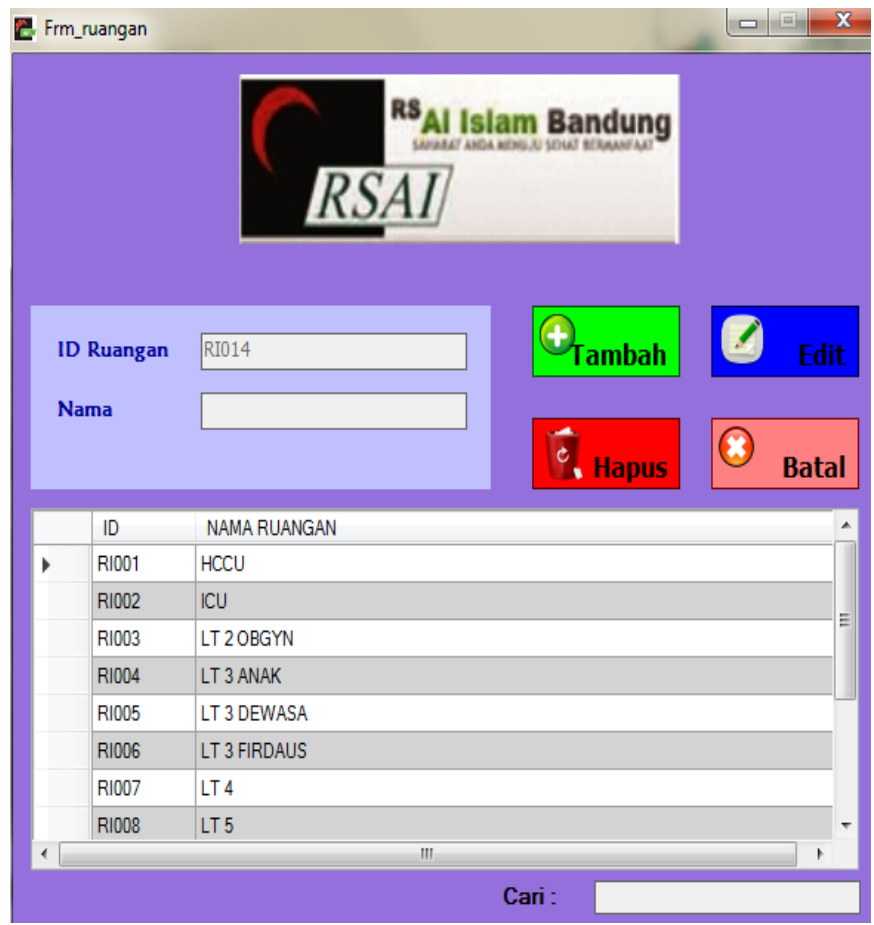

Gambar 18. Olah Data Ruangan

Sumber : Penulis 2017

8. Olah Data Analisa

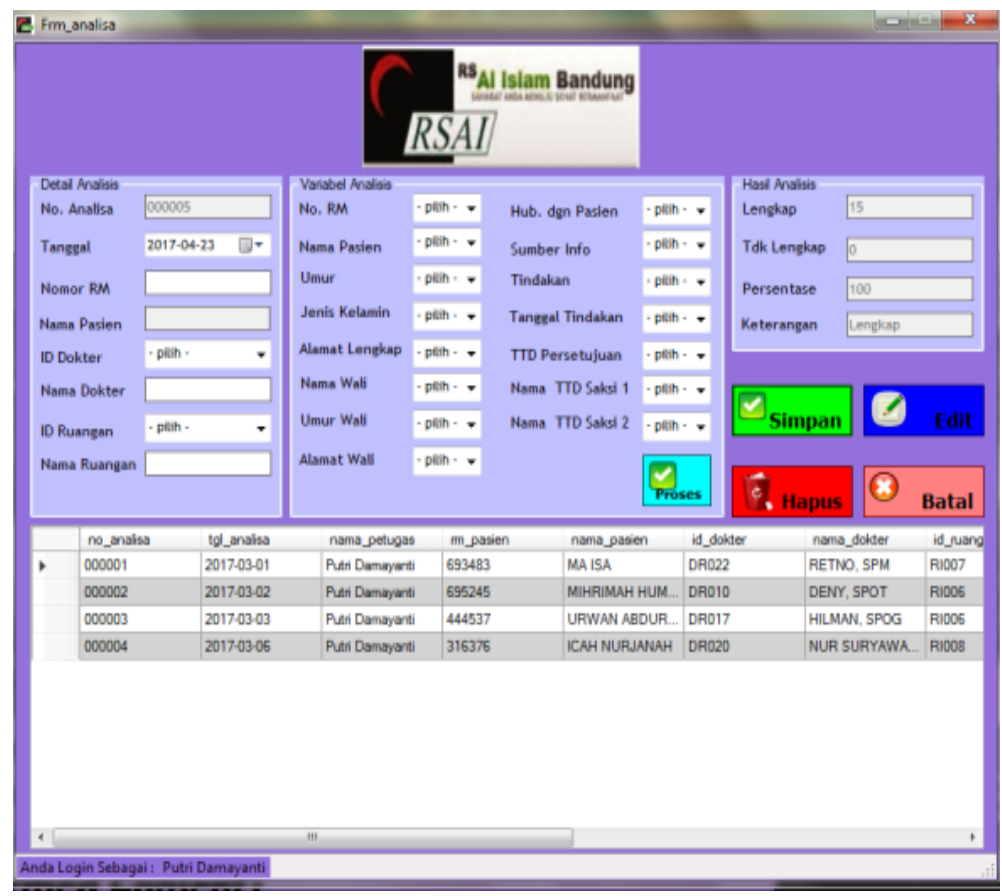

Gambar 19. Olah Data Analisa

Sumber : Penulis 2017 
9. Set Laporan Berdasarkan Periode

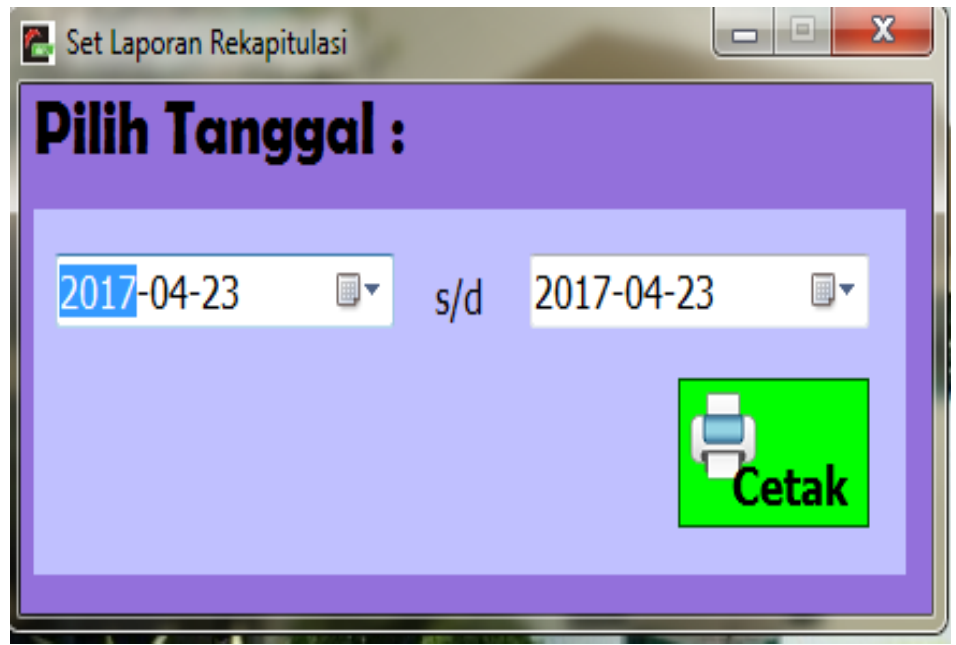

Gambar 20. Set Laporan Berdasarkan Periode Sumber : Penulis (2017)

10. Set Laporan Berdasarkan Kategori

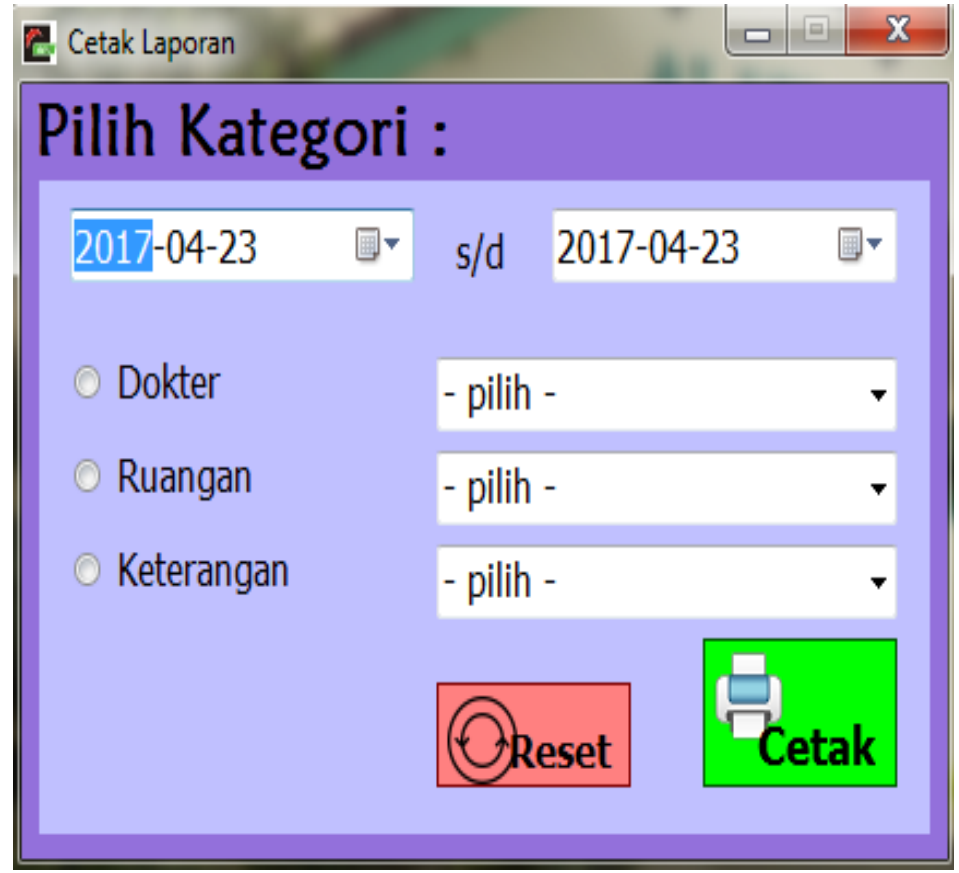

Gambar 21. Set Laporan Berdasarkan Kategori

Sumber : Penulis 2017

11. Laporan Hasil Analisia Kelengkapan Informed Consent Perhari 


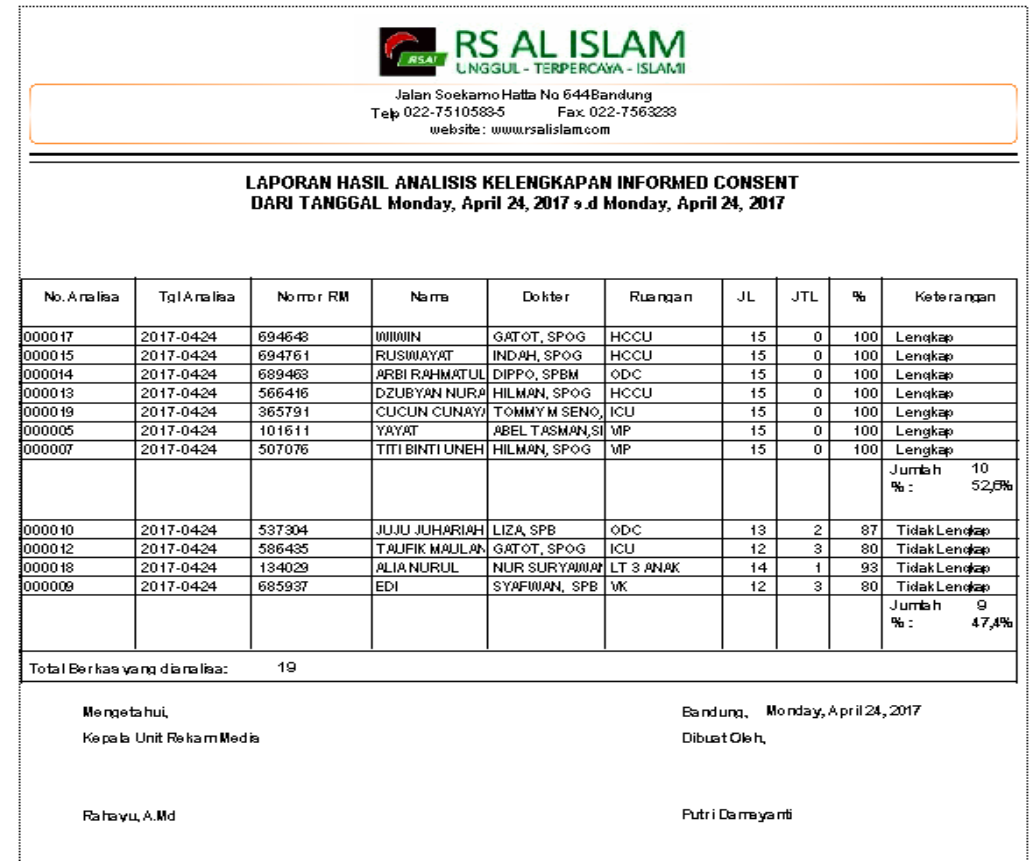

Gambar 22. Laporan Hasil

Analisia Kelengkapan Informed Consent Perhari Sumber: Penulis 2017

12. Laporan Hasil Analisia Kelengkapan Informed Consent Perbulan

RS AL ISLAM

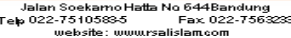

LAPORAN HASIL ANALISIS KELENGKAPAN INFORMED CONSEET

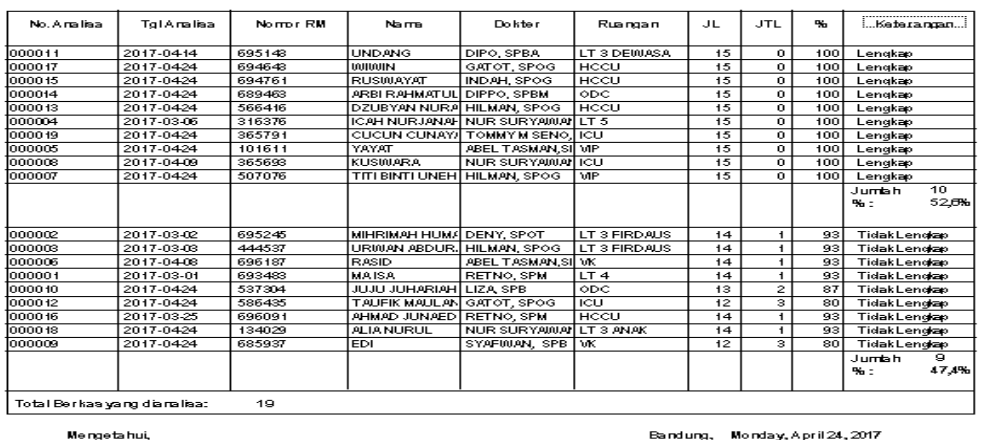

Gambar 23. Laporan Hasil Analisia Kelengkapan Informed Consent Perbulan Sumber : Penulis 2017 
13. Tampilan Laporan Hasil Analisia Kelengkapan Informed Consent Berdasarkan Kategori Dokter

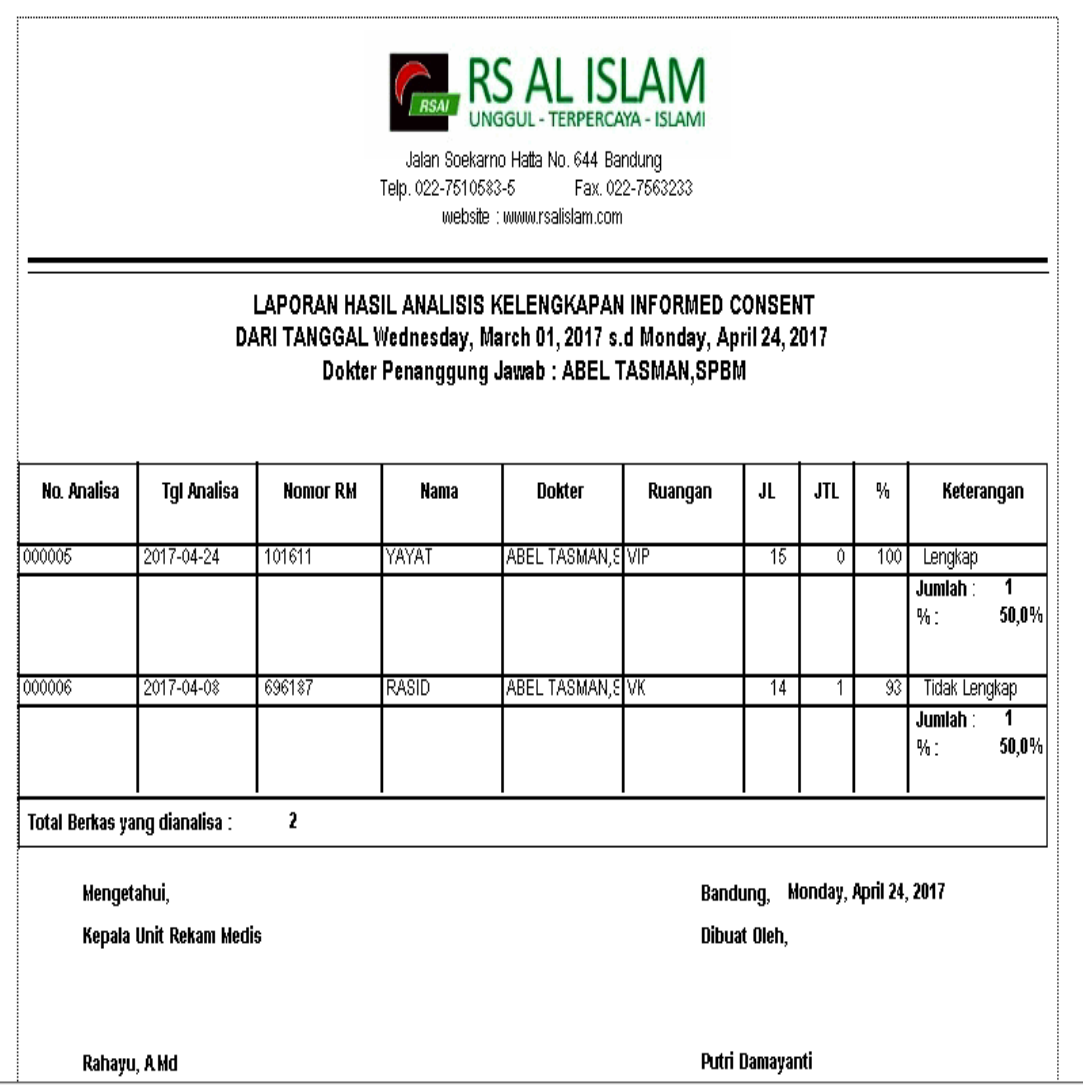

Gambar 24. Laporan Hasil Analisia Kelengkapan Informed Consent Berdasarkan Kategori Dokter

Sumber : Penulis 2017

14. Tampilan Laporan Hasil Analisia Kelengkapan Informed Consent Berdasarkan Kategori Ruangan 


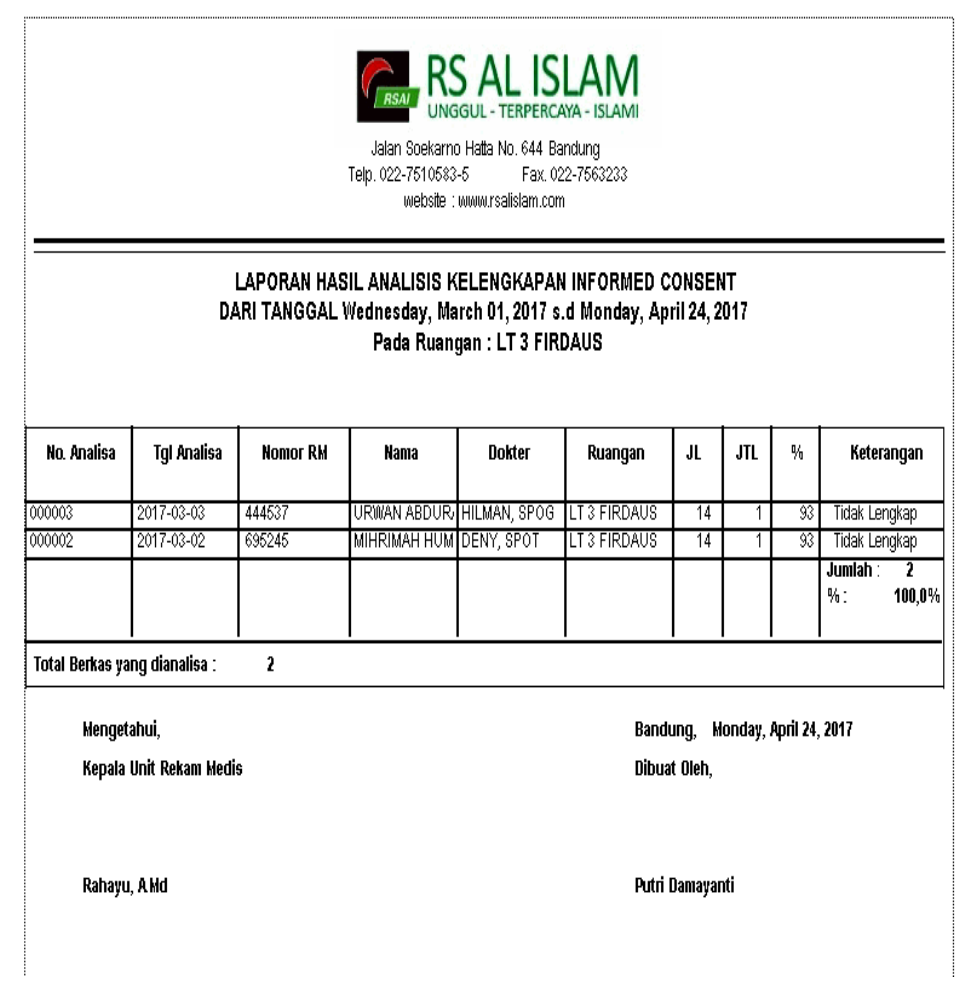

Gambar 25. Laporan Hasil Analisia Kelengkapan Informed Consent Berdasarkan Kategori Ruangan

Sumber : Penulis 2017

\section{P. Spesifikasi Hardware dan Software}

1. Perangkat Keras (Hardware)

Perangkat keras adalah komponen- komponen yang dapat dilihat secara fisik yang membentuk suatu sistem sehingga komputer dapat menjalankan tugasnya dengan baik. Spesifikasi hardware minimal yang harus diberikan adalah sebagai berikut :

a. Processor Intel Pentium IV dengan mecepatan minimal $1.6 \mathrm{GHz}$

b. Harddisk 40GB, Minimal Free Space $50 \mathrm{Mb}$

c. RAM Minimal 1 GB

d. VGA minimal mendukung resolusi $1024 \times 768$ px dan mendukung kedalaman warna minimal 16bit

e. Monitor CRT/LCD minimal 14" (Mendukung resolusi 1024x768px dan kedalaman warna minimal 16 bit)

f. Printer

g. Keyboard dan Mouse Standar

2. Perangkat Lunak (Software)

a. Sistem Operasi Windows XP Profesional ke atas.

b. Aplikasi Bahasa Pemograman Microsoft Visual Studio 2010

c. Aplikasi DatabaseMicrosoft Access

PENUTUP

Kesimpulan 
Dari penelitian dan tulisan yang telah penulis uraikan, maka dapat ditarik kesimpulan sebagai berikut:(1) Aplikasi yang dirancang ini diusulkan untuk dapat membantu pihak Rumah Sakit Al Islam Bandung dalam mengolah analisa kelengkapan pengisisan Informed Consent secara komputerisasi.(2) Penggunaan sitem ini di rancang semudah mungkin, sehingga sistem ini menjadi userfriendly dan prosesnya pun lebih cepat dan tepat sasaran.(3) Proses perancangan sistem informasi kelengkapan pengisian formulir Informed Consent menggunakan metode waterfall dan penggambaran fungsionalitas sistem menggunakan bahasa pemograman Object Oriented Program (OOP) yaitu Microsoft Visual Studio 2010.(4) Cara tepat untuk mengatasi permasalahan yang sedang terjadi di Rumah Sakit Al Islam Bandung adalah dengan cata menggantinya yaitu dengan cara mengimplementasikan program yang telah dirancang penulis dengan menggunakan bahasa pemrograman Microsoft Visual Studio 2010 dan database Microsoft Acces 2007.

Saran

Penulis memberikan saran sebagai masukan dan motivasi yang diharapkan dapat membangun kepada pihak Rumah Sakit Al Islam Bandung, yaitu sebagai berikut :

1. Perlu adanya mengadakan sosialisasi kembali terhadap Standar Prosedur Operasional (SPO) pembuatan informed consent kepada pihak terkait agar pengisian formulir informed consent dilakukan secara lengkap.

2. Perlu adanya proses analisa kelengkapan pengisian formulir informed consent yang dilakukan secara khusus agar semua format isian yang tidak lengkap dapat diketahui lebih rinci.

3. Perlu adanya sistem informasi analisa kelengkapan pengisian formulir informed consent agar proses analisa dapat efisien dan efektif serta menghasilkan laporan kelengkapan yang akurat dan rinci.

\section{DAFTAR PUSTAKA}

Depkes RI Dirjen Yanmed. 2006. Pedoman Penyelenggaraan dan Prosedur Rekam Medis Rumah Sakit Di Indonesia Revisi II. Bakti Husada. Jakarta

Hatta, Gemala R . 2013. Pedoman Manajemen Informasi Kesehatan di Sarana Pelayanan Kesehatan [Revisi 11]. Universitas Indonesia. Jakarta

PERMENKES No 269 tahun 2008 Tentang Rekam Medis.

Undang-Undang Republik Indonesia Nomor 44 tahun 2009 tentang rumah sakit.

Undang-Undang Republik Indonesia No. 29 tentang Praktik Kedokteran

Jogiyanto. 2010.Analisis dan Desain Sistem Informasi [ Edisi IV]. Andi Ofset. Yogyakarta

Rosa A.S dan M. Shalahudin. 2014. Rekayasa Perangkat Lunak Terstruktur dan Berorientasi Objek. Informatika Bandung. Bandung

Sutanta, Edhy. (2003). Sistem Informasi Manajemen. Graha Ilmu. Yogyakarta

Sugiyono. 2009.Metode Penelitian Kuantitatif dan Kualitatif. CV.Alfabeta. Bandung

Ladjamudin, bin Al-Bahra. (2005). Analisis dan Desain Sistem Infomasi. Graha Ilmu. Yogyakarta.

Ratman, Desrriza. (2013). Aspek Hukum Informed Consent Dan Rekam Medis Dalam Transaksi Terapeutik. Jakarta 